\title{
Honoursdidactiek in een leergang voor honoursdocenten ${ }^{*}$
}

\author{
Hanne ten Berge \& Rob van der Vaart ${ }^{* *}$
}

In dit artikel onderbouwen we dat de strategieën voor goede honoursdidactiek voor studenten - het creëren van een community, gebonden vrijheid en het ontwikkelen van academische competenties (Wolfensberger, 2012) - ook werkzaam zijn in de opzet van een leergang voor docenten die honoursstudenten begeleiden. We betogen dat het ontwerp van de leergang, dat gebaseerd is op deze strategieën, het succes van de leergang in termen van de leeropbrengst bepaalt. Voor dit artikel hebben we onderzoek verricht naar de eerste drie edities van de leergang honours teaching van de Universiteit Utrecht. We gebruiken hierin de evaluatiegegevens van de leergang en interviews met alumni uit de drie leerganggroepen.

\section{Inleiding}

Sinds de jaren negentig zijn er op de Universiteit Utrecht honoursopleidingen, speciaal voor studenten die extra uitdaging zoeken (Scager, 2013). Deze startten als experimenten, getrokken door enkele enthousiastelingen. Geleidelijk aan zijn ze uitgebouwd. $\mathrm{Nu}$ is er honoursonderwijs in elk van de zeven faculteiten en is er een universiteitsbreed honoursprogramma.

Het college van bestuur ziet het belang van de honoursprogramma's en wil de kwaliteit ervan verder uitbouwen door resultaten van onderzoek naar honoursonderwijs te verspreiden, ervaringen over wat werkt uit te laten wisselen en netwerkvorming te bewerkstelligen, zodat ook in de toekomst samenwerking en uitwisseling rond honoursonderwijs plaatsvindt. Ook bij docenten blijkt daar behoefte aan te bestaan. Een van de uitvloeisels daarvan is dat in 2011 door het Centre of Excellence in University Teaching een leergang honours teaching (didactiek) is gestart voor docenten die honoursstudenten begeleiden. Inmiddels is de vierde leergang honours teaching afgerond. Evaluaties tijdens de leergang en interviews met ex-deelnemers na een aantal maanden geven zicht op de kwaliteit van de

* Dit artikel is tevens aangeboden voor plaatsing in een monografie van de NCHC commissie Teaching and Learning.

** Hanne ten Berge (j.h.tenberge@uu.nl) is senior onderwijskundig adviseur bij het Centrum voor Onderwijs en Leren van de Universiteit Utrecht. Haar werk betreft curriculumontwikkeling, met een expertise in talentontwikkeling en ambitieuze studiecultuur. Ze werkt als adviseur voor verschillende honoursopleidingen in het hoger onderwijs in Nederland. Zij is tevens programmaleider van de leergang honours teaching van de Universiteit Utrecht. Rob van der Vaart (r.j.f.m.vandervaart@uu.nl) is de honours dean van de Universiteit Utrecht en dean van het University College Utrecht. Hij is tevens programmaleider van de leergang honours teaching van de Universiteit Utrecht. 
leergang en het leereffect dat deze oplevert. Voor ons onderzoek konden we gebruik maken van de gegevens van de eerste drie leergangen.

In dit artikel beschrijven we de ontwerpcomponenten voor de leer- en doceeromgeving van de leergang en betogen we dat de strategieën voor goede honoursdidactiek voor studenten, zoals Wolfensberger (2012) die benoemt - het creëren van een community, gebonden vrijheid en het ontwikkelen van academische competenties - ook werkzaam zijn in de opzet van een leergang voor docenten die honoursstudenten begeleiden. We beargumenteren dat het ontwerp van de leergang, dat gebaseerd is op deze strategieën, het succes van de leergang in termen van de leeropbrengst bepaalt. Daar kunnen andere opleidingen voor honoursdocenten gebruik van maken.

We starten met een bespreking van de kenmerken van passende didactiek voor honoursstudenten zoals die uit onderzoeksliteratuur naar voren komen. Vervolgens beschrijven we het ontwerp van de leergang.

Dit artikel is gebaseerd op onderzoek naar de leeropbrengsten van de eerste drie edities van de leergang honours teaching die op de Universiteit Utrecht zijn aangeboden. De methode en resultaten van dit onderzoek worden in het volgende deel van dit artikel gepresenteerd. Daarbij gaan we in op de centrale vraag: leiden de drie belangrijke strategieën die voor honoursonderwijs aan studenten gelden (vergroten van academische competentie, bieden van vrijheid om eigen keuzes te maken en communityvorming) ook tot goede leerresultaten in een leergang voor honoursdocenten? We eindigen met een conclusie en discussie over de toepasbaarheid van deze resultaten.

\section{Honoursdidactiek}

De omvang van de empirische onderzoekliteratuur over passende didactiek voor honoursstudenten in het hoger onderwijs is beperkt (Achterberg, 2005; Clark, 2000; Rinn \& Plucker, 2004; Scager, 2013; ). De meeste van deze literatuur is beschrijvend en gericht op casussen. Wel is er veel empirische onderzoeksliteratuur over didactiek voor begaafde basisschool- en middelbareschoolleerlingen die de effectiviteit van bepaalde strategieën aangeeft. Uit deze beschrijvende en empirische literatuur komen drie factoren naar voren die essentieel zijn voor honoursdidactiek: het vergroten van academische competentie; vrijheid geven in wat studenten willen leren en hoe ze dat willen aanpakken; en communityvorming (Wolfensberger, 2012).

Het vergroten van academische competentie is een eerste essentieel onderdeel van honoursonderwijs, waarbij de nadruk veelal wordt gelegd op verrijking (anders en verdiepend werken) in plaats van op versnellen en meer van hetzelfde, zodat studenten extra mogelijkheden krijgen om hun talenten te ontwikkelen en tot bloei te laten komen. De leeractiviteiten kunnen rijker zijn in theorie en praktijk: door meer intellectuele uitdaging te bieden en aan te sturen op integratie, 
multidisciplinaire aanpak, kritische verwerking en verwerking van rijk materiaal (Achterberg, 2005). Dat past bij de behoefte van honoursstudenten "who are more academically confident, have greater intellectual interests, and are more willing to challenge their accepted values, beliefs, and ideas" (Kaczvinsky, 2007, p. 93). Begaafde studenten voelen zich niet uitgedaagd door de voorgestructureerde curssussen die het onderwijs domineren. Volgens Reis en Renzulli (2010) moeten de leeractiviteiten niet standaard zijn, maar verrijking, differentiatie, versnelling en verbeterde en gevorderde lessen bieden. Hogere-orde denkvaardigheden en onderzoeksgericht leren passen in deze behoeften (Van Tassel-Baska \& Brown, 2007; Shore \& Kanevsky, 1993), evenals ontdekkend leren, minder scaffolding, minder voorstructurering (Snow \& Swanson, 1992) en situated learning in de vorm van authentieke, open taken (Gruber \& Mandl, 2000).

Een tweede belangrijk element in de vormgeving van honoursonderwijs is het bieden van vrijheid om eigen keuzes te maken (Wolfensberger, 2012). In combinatie met rijke leeractiviteiten biedt dit studenten uitdaging. Rogers (2007) stelt dat het aanbieden van mogelijkheden om ook eens zelfstandig te werken belangrijk is in de ontwikkeling van onderwijs voor begaafde leerlingen in het primair en voortgezet onderwijs. Kanevsky en Keighly (2003) vonden dat het geven van keuze en controle over hun leerproces begaafde leerlingen hielp om verveling te voorkomen. Het onderzoek geeft ook aanwijzingen voor de rol van de docent. Begaafde leerlingen prefereren een zorgzame docent die zijn leerlingen autonomie geeft (Kanevsky \& Keighly, 2003; Marra \& Palmer, 2004).

Van Eijl, Wolfensberger en Pilot (2008) benadrukten in hun inventarisatie van honoursprogramma's in de Verenigde Staten de werking die uitgaat van communityvorming voor een groep honours studenten. De community bevordert productieve interactie tussen studenten, docenten en andere professionals, waardoor studenten leerervaringen opdoen. Dit belang wordt ondersteund door constructivistische leertheorieën die stellen dat kennis geconstrueerd wordt in interactie met anderen. Ook kunnen studenten binnen de community-activiteiten bepaalde vaardigheden ontwikkelen, zoals organisatorische en leiderschapsvaardigheden, afhankelijk van het karakter van het betreffende honoursprogramma (Van Ginkel, Van Eijl, Pilot, \& Zubizarreta, 2012).

Uit het onderzoek van Wolfensberger (2012) komt naar voren dat alle drie de componenten belangrijk zijn. Er kan er geen worden weggelaten. In combinatie zijn ze bevorderlijk voor een optimaal leerklimaat.

Motivatietheorieën bieden een onderbouwing voor het belang van deze drie componenten. De zelfdeterminatietheorie van Deci en Ryan (1985) is bruikbaar gebleken om het verschil in leerstrategieën, prestaties en doorzettingsvermogen tussen studenten te verklaren. "Mensen die een authentieke motivatie hebben [...] zijn meer geïnteresseerd, enthousiast en hebben meer vertrouwen, wat zich uit in betere prestaties, doorzettingsvermogen en creativiteit, evenals in verhoogde vitaliteit, eigenwaarde en welzijn in het algemeen" (Ryan \& Deci, 2000, eigen vertaling). De zelfdeterminatietheorie stelt dat menselijke motivatie grotendeels 
gebaseerd is op een samenstelling van aangeboren psychologische behoeften: interpersoonlijke relaties, competentie en zelfbeschikking. De drie strategieën die door Wolfensberger (2012) geïdentifeerd zijn als essentiële elementen van honoursdidactiek (community, academische competentie, gebonden vrijheid) zijn nauw gerelateerd aan deze drie behoeften. Interpersoonlijke relaties, of het gevoel verbonden te zijn met belangrijke anderen, is een belangrijk onderdeel van een community. Uitdagende academische taken aankunnen (academische competentie) vergroot het gevoel van competentie in het algemeen. Een omgeving waarin studenten autonomie hebben en eigen keuzes kunnen maken bevordert het gevoel van competentie, wat op zijn beurt de intrinsieke motivatie bevordert.

Theorieën over honoursdidactiek en motivatietheorieën schragen het ontwerp van de leergang honours teaching. We zullen nu eerst het programmaformat van deze leergang beschrijven.

\section{De leergang honours teaching}

Het format van onze leergang voor docentprofessionalisering in honoursdidactiek is gebaseerd op het model van de langlopende leergang 'Onderwijskundig leiderschap' van de Universiteit Utrecht, die georganiseerd wordt door haar Center of Excellence in University Teaching (CEUT). Deze leiderschapsleergang, die veel omvangrijker is dan de leergang honours teaching, is zeer succesvol (Grunefeld \& Wubbels, 2009). Voor onze leergang namen we een aantal organiserende principes over van deze leergang 'Onderwijskundig leiderschap':

- Breng stafleden uit verschillende faculteiten en departementen bij elkaar in een groep van maximaal zestien geselecteerde deelnemers;

- Zorg ervoor dat de deelnemers veel gelegenheid hebben om informeel met elkaar te praten en elkaar te leren kennen;

- Nodig experts uit die een overzicht kunnen geven van state-of-the-art-inzichten, die dit op een interactieve manier kunnen brengen en die de deelnemers de ruimte geven om nieuwe kennis te verbinden met hun eigen ervaringen;

- Laat de deelnemers een interventie doen in hun dagelijkse werk (in ons geval: in hun eigen honoursonderwijs); de deelnemers werken aan hun interventies gedurende de looptijd van de leergang en bespreken de voortgang tijdens de bijeenkomsten, in kleine groepjes van drie tot vier deelnemers, die elkaar over de interventie bevragen en suggesties geven;

- Stel de deelnemers een uitgebreide hoeveelheid literatuur en onderzoeksbevindingen ter beschikking (leestafel en literatuurpakket) waaruit zij inspiratie kunnen opdoen afhankelijk van hun eigen vragen en behoeften;

- Geef de mogelijkheid te discussiëren en debatteren over alle aspecten van de leergang, voornamelijk over de inhoud van het gebodene en de doceerpraktijk van de deelnemers;

- Kies een cursuslocatie waar de deelnemers echt weg zijn uit hun dagelijkse praktijk. 
Deze ontwerpcomponenten weerspiegelen enkele van de succesfactoren voor professionele ontwikkeling voor docenten zoals Garet, Porter, Desimone, Birman \& Yoon (2001) die identificeerden:

- Een actieve rol voor de deelnemers in het proces: de beperkte groepsomvang maakt veel interactie mogelijk, er zijn veel momenten voor informeel contact, interactie en transfer naar de eigen praktijk staan centraal in de bijeenkomsten en in het werken aan de interventie, deelnemers bepalen zelf mede welke onderwerpen aan bod komen;

- Samenhang tussen de verschillende elementen in een professionaliseringscursus: deelnemers gebruiken theorie uit aangereikte literatuur en bijdragen van gastsprekers, evenals ervaringen die ze van anderen horen tijdens de bijeenkomsten, in hun interventie en de ervaringen met hun interventie brengen zij weer in de bijeenkomsten in. Er wordt steeds teruggegrepen op in eerdere bijeenkomsten besproken onderwerpen;

- Focus op de academische discipline waar deelnemers uit komen en de daarbij behorende onderwijspraktijk: deelnemers geven op basis van wat ze in de leergang krijgen aangereikt een interventie in hun eigen honoursonderwijs vorm en er is veel gelegenheid ervaringen en vragen uit de eigen onderwijspraktijk in te brengen.

Onderzoek heeft aangetoond dat samenwerkend leren in een team of groep ook voor professionele ontwikkeling een succesfactor is, evenals het gebruik van reflectie over het eigen handelen ( reflection on action) (Clausen, Aquino, \& Wideman, 2009). De programmaleiders van de leergang honours teaching passen die toe in de besprekingen van de interventies die deelnemers in hun onderwijspraktijk uitvoeren. Deelnemers bespreken met elkaar hoe succesvol hun interventies waren en in hoeverre veranderingen in hun aanpak tot andere uitkomsten hebben geleid. Deze reflectie vindt plaats in de intervisiegesprekken die in de bijeenkomsten zijn ingebouwd.

Het format van onze leergang honours teaching is samengevat in figuur 1.

\section{Leeropbrengsten}

In deze paragraaf gaan we in op de uitkomsten van de evaluaties van de eerste en de tweede bijeenkomst van elke leergang en van de gehele leergang in de derde bijeenkomst. Hiermee laten we zien dat de leergang positief gewaardeerd wordt door de deelnemers en dat zij zelf belangrijke leeropbrengsten ervaren als gevolg van de leergang. Dit is een opstap naar het deel van dit artikel dat ingaat op de centrale onderzoeksvraag: zijn de strategieën voor goede honoursdidactiek voor studenten, zoals Wolfensberger (2012) die benoemt - het creëren van een community, gebonden vrijheid en het ontwikkelen van academische competenties ook werkzaam in de opzet van een leergang voor docenten die honoursstudenten begeleiden? 


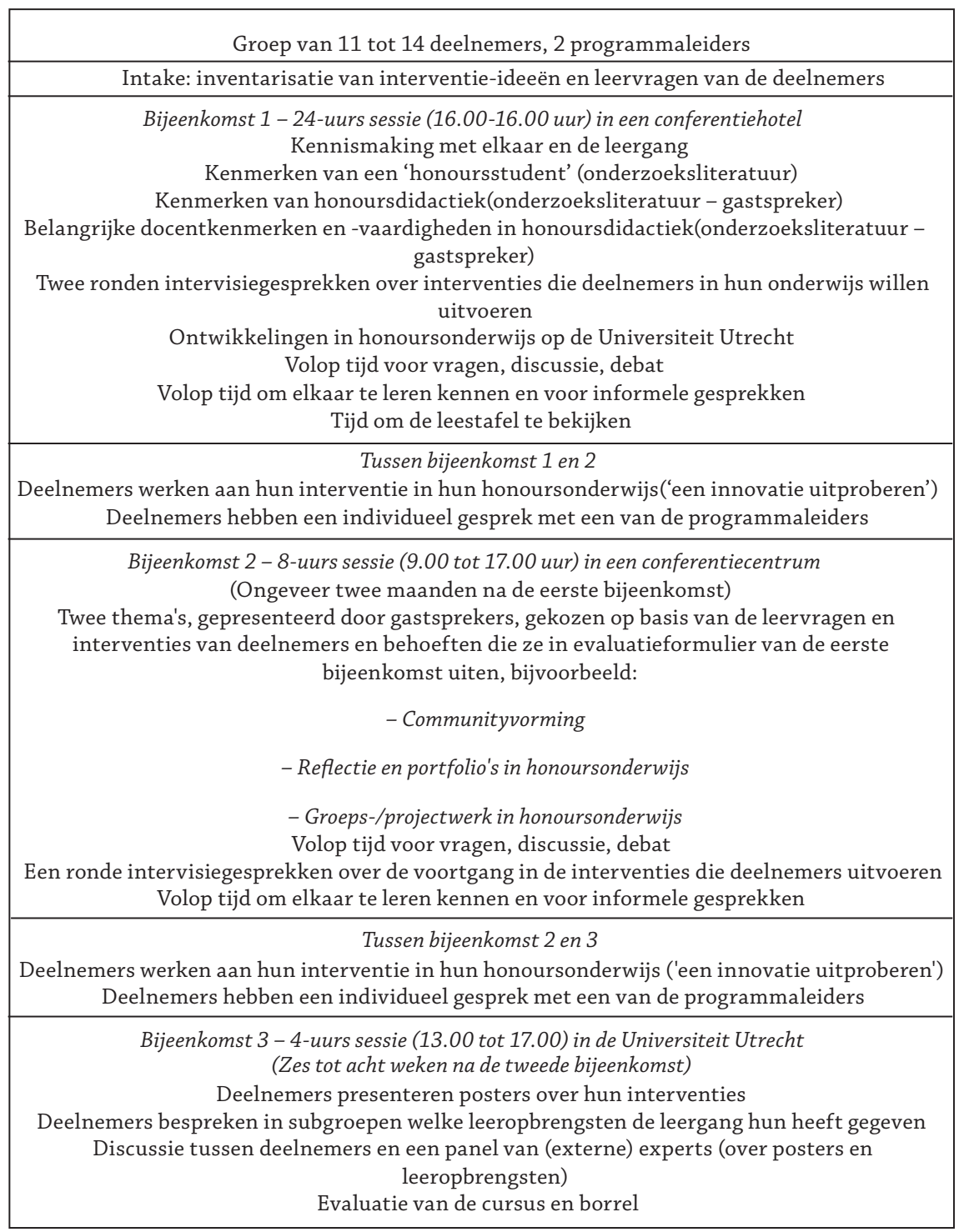

\section{Figuur 1 Format van de leergang honours teaching}

Figuur 1 laat zien dat de eerste twee bijeenkomsten van onze leergang honours teaching gericht zijn op inleiding in en discussie over evidence-based kennis over honoursdidactiek. We hebben gekeken naar de eerste drie keer dat de leergang is gegeven. We hebben dan ook data van zes van deze bijeenkomsten. De deelnemers, allen ervaren docenten, waren zeer positief over de kennis en inzichten die ze hebben opgedaan ten aanzien van honoursdidactiek:

- $\quad$ 4,5 of hoger op een vijfpunts-Likertschaal voor vier van de bijeenkomsten; 
- $\quad 4,1$ voor een vijfde bijeenkomst;

- en een teleurstellende 3,4 voor een bijeenkomst waarin een van de gastsprekers geen sterke empirische evidentie presenteerde voor zijn aanpak van honoursdidactiek en er niet in slaagde er met de deelnemers een open en goede discussie over te hebben.

De evaluaties met het panel in de derde bijeenkomst van elke leergang bevestigen dat de deelnemers tevreden waren over de leergang. Ze rapporteerden dat ze vele nieuwe inzichten hadden opgedaan en wilden de uitwisseling met elkaar over honoursdidactiek graag voortzetten na de leergang. Ze meldden dat ze handvatten hebben gekregen om de behoeften van honoursstudenten te begrijpen en hun honoursdidactiek te verbeteren. Een andere opmerking die meerdere deelnemers geven is dat ze de theoretische inzichten die tijdens de leergang zijn besproken en de koppeling daarvan aan de praktijk van het honoursonderwijs als zeer bruikbaar beoordelen. Een voorbeeld van een reactie is: "De lezingen, de discussies, de input vanuit een grote variëteit aan honoursprogramma's - het veranderde me. Het heeft me naar een hoger niveau van begrip getild".

Veertien deelnemers gaven uitgebreide feedback na de leergang, in antwoord op een schriftelijke vragenlijst (alleen de eerste groep) of in een interview (alle drie de groepen). Bijna allemaal rapporteerden ze dat ze hun benadering en aanpak van honoursdidactiek hebben veranderd door toedoen van de leergang. Verschillende deelnemers zeiden dat ze zich nu realiseren dat honoursdidactiek betekent dat je uit je comfortzone moet komen en dat dit niet alleen geldt voor de studenten maar ook voor de docenten. Als gevolg daarvan zijn ze meer gaan experimenteren in hun honourscursussen en hebben ze meer afwisseling aangebracht in hun doceerstrategieën. Een belangrijk resultaat is ook dat sommige deelnemers rapporteren dat ze dankzij de leergang meer authentiek durven zijn. Eén deelnemer schreef: "Het heeft me veel zekerder gemaakt in het lesgeven [...]. Ik ben vrijer geworden in het aanbrengen van veranderingen in mijn lessen, het experimenteren met nieuwe onderdelen en het structureel gebruik van reflectie door de studenten. [...] Ik durf dan ook meer mijn ideeën te 'omhelzen' en concreet vorm te geven". Twee respondenten noemden meer persoonlijk contact met studenten als duidelijke verandering na deelname aan de leergang. "Ik neem meer tijd om naar studenten te luisteren. Niet alleen in hun reflectie, maar ook in de discussie in de klas - ik merk dat ik er beter in slaag om een vrij stille, intensieve thinking zone te genereren waarin we met z'n allen nieuwe kennis produceren," zei een van hen. Een ander zei over het toegenomen persoonlijke conctact: "Meer dan het geval was benader ik studenten 'op maat,' stimuleer ik hen om met de vrijheid die het curriculum biedt hun ambities en interesses te ontdekken en in te vullen".

Veel respondenten noemden veranderingen in hun honoursdidactiek als resultante van de leergang honours teaching, zoals al duidelijk werd in de citaten hiervoor. De docenten gebruikten verschillende bewoordingen om dit duidelijk te maken. Hun antwoorden maken duidelijk dat de leergang hen heeft geholpen een helikopterview te ontwikkelen op de essentiële kenmerken van honoursdidactiek en om deze te vertalen naar de praktijk van hun honoursonderwijs. "Ik werd kriti- 
scher over het format van mijn honours seminars [...]. Ik reflecteer meer over het honoursprogramma en voel me in staat om studenten meer vrijheid te bieden". Of: "De leergang heeft me geholpen me bewust te worden van wie de honourstudent is en wat dit betekent voor doceren en leren". Een andere docent zei: "Ik heb mijn cursus aangepakt. Het effect van het ontwerp is dat nu meer studenten hun mond opendoen; dat er sowieso meer inbreng is. Het ontwerp behelsde een opdracht in de klas. Ik ben me bewuster van wat er gebeurt in de klas. [...] Nuances vallen me nu op".

Een ander resultaat van de leergang is het effect op de selectie van honoursstudenten. Een van de docenten, die verantwoordelijk is voor de toelatingen tot het honoursprogramma in haar departement, meldde: "Ik heb een duidelijker beeld gekregen van wat kenmerkend is voor honoursstudenten. Het gaat niet per se om hoge cijfers, maar om 'willen', 'kunnen' en een bepaalde motivatie/ drive. Daardoor kijk ik met een andere blik naar kandidaten. Niet alleen naar hun cijfers dus, maar 'wat wil je uit het honoursprogramma halen'? Mijn beeld van hoe ik tegen studenten aankijk is verschoven en ook wie ik toelaat tot het programma".

Veel van de opmerkingen in de evaluaties en interviews suggereren dat deelnemers aan de leergang meer zelfvertrouwen hebben opgedaan in hun aanpak van honoursdidactiek en ervoor openstaan om meer risico te gaan nemen. Sommige reacties waren behoorlijk expliciet daarover, bijvoorbeeld: "Het heeft me meer zelfvertrouwen gegeven om niet alles dicht te timmeren. Ik was al wel flexibel, maar ik vond het eng. Ik wilde toch de controle houden. Het heeft me de bevestiging gegeven dat ik op de goede weg zit. Dat wat ik deed nog niet genoeg was. Nu: ik hoef geen controle te hebben. Ook al gebeurt er iets anders dan ik had verwacht, is het ook nog goed".

Sommige geïnterviewden, veelal zeer ervaren docenten, zijn nauwelijks of geen andere didactiek gaan toepassen als gevolg van de leergang. Het effect ligt bij hen meer op versteviging van hun ideeën en bevestiging van de al ingeslagen weg. Zoals een van hen zei: "Ik heb leren kijken naar honours. Ik duid het nu positiever. Ik kwam van ver. Ik zie dat het ook voor onze studenten zinvol is: studenten opleiden tot zinvolle burgers, leidinggevende burgers, om de studenten beter te maken, oordeelkundige, verstandige mensen opleiden. Om maatwerk te bieden: meer mogelijkheid geven aan de bovenkant. [...] Ik doe nu niet iets anders als docent. Wel in het uitdragen van wat ik wil. Ik herken veel van de didactiek. Ik herken mijn overtuigingen en heb ze in groter perspectief kunnen plaatsen".

Alle uitkomsten van ons onderzoek wijzen erop dat onze leergang voor professionele ontwikkeling in honoursdidactiek stevige en betekenisvolle leeropbrengsten heeft. Als ontwerpers van de leergang nemen we aan dat dit succes grotendeels te danken is aan het feit dat de leergang de strategieën voor goede honoursdidactiek reflecteert: uitdagende academische inhoud, vrijheid voor de deelnemers om hun eigen leren te sturen en de vorming van een sterke community. In het vervolg van dit artikel zullen we onderzoeken in hoeverre de docenten zelf hun positieve leer- 
opbrengsten toeschrijven aan de drie vormgevingscomponenten van deze leergang.

\section{Methode}

\section{Deelnemers}

De eerste drie edities van de leergang honoursdidactiek die zijn aangeboden door de Universiteit Utrecht hadden bij elkaar 38 deelnemende docenten (respectievelijk 11, 14, 13). De docenten kwamen van alle faculteiten van de universiteit, in gemengde groepen: bètawetenschappen; diergeneeskunde; geesteswetenschappen; geneeskunde; geowetenschappen; recht, economie, bestuur en organisatie; sociale wetenschappen; en de twee university colleges, University College Utrecht en Roosevelt Academy. De standaardprocedure was dat deelnemers aan het eind van de eerste en de tweede bijeenkomst een evaluatieformulier invulden en in de derde bijeenkomst de totale leergang mondeling evalueerden in gesprek met een panel van mensen van binnen en buiten de Universiteit Utrecht die met de deelnemers ook de resultaten van hun interventies bediscussieerden.

De evaluatieformulieren boden ruimte voor beantwoording van open vragen waarin de docenten konden aangeven wat zij de sterkste en zwakste aspecten van de bijeenkomsten vonden. Deze open antwoorden laten veel zien van wat de deelnemers de succesfactoren van de leergang vonden. De evaluatieformulieren bieden door de combinatie van gesloten en open vragen evaluatie van het eerste en tweede niveau volgens de indeling van Guskey (2005/2006), namelijk de reactie van deelnemers (in de gesloten vragen) en zicht op de leeropbrengsten in de reflecties van de deelnemers (in de open vragen).

De mondelinge evaluatie van de gehele leergang in gesprek met het panel tijdens de derde en laatste bijeenkomst werd door de deelnemers gezamenlijk voorbereid en uitgevoerd. Ook deze evaluatie geeft ons daardoor spontane feedback en inzichten in wat de docenten factoren vonden die de leeropbrengst van de leergang verklaarden en leverde een evaluatie van het tweede niveau (Guskey, 2005/2006).

Daarnaast hebben we zeven interviews gehouden met docenten uit alle drie de edities van de leergang. We vroegen hierin welk element uit de leergang hen het meeste had aangezet tot verandering in hun honourspraktijk, wat leidde tot spontane uitspraken (reflectie over het toepassen van nieuwe kennis en vaardigheden; het vierde niveau van evaluatie volgens Guskey, 2005/2006). Aan het eind van elk interview vroegen we hun of ze de drie strategieën herkenden die we in de leergang hebben toegepast en die volgens de beschrijvende en empirische literatuur essentieel zijn voor honoursdidactiek: (a) het vergroten van academische competentie; (b) vrijheid geven in wat deelnemers willen leren en hoe ze dat willen aanpakken; (c) communityvorming. Dit gedeelte leidde tot de enige gestructureerde feedback die we in het navolgende deel zullen gebruiken. De interviews zijn afge- 
Ontmoeting; Uitwisseling; Veel nieuwe contacten; Delen van ervaringen; Gemeenschappelijke drive; Hoe stimulerend de groep is; Enthousiasme/betrokkenheid van de deelnemers; Gedeelde visie; Leuke groep en vaak interessante discussies; Uitwisseling van ervaringen; Leren van elkaar; Enthosiasme; Met collega's praten over doceren; De ervaringen van andere docenten horen; Positief-kritische sfeer in de groep; Interactie tussen alle aanwezigen; Groepsdynamiek; Zorgen en oplossingen delen; Contact met collega's uit andere faculteiten; Mijn netwerk uitbreiden; Betrokken groep; Geweldige sfeer; Open opstelling deelnemers en constructieve feedback.

Figuur 2 De leergang honours teaching als een community: enkele uitspraken uit de evaluatieformulieren

nomen door de auteurs van dit artikel, tevens de programmaleiders van de leergang.

\section{Resultaten \\ Bijeenkomsten één en twee van de drie edities van de leergang resulteerden in meer dan zeventig ingevulde evaluatieformulieren. Een van de open vragen peilde naar wat de docent ten aanzien van de bijeenkomst het meest in positieve zin was opgevallen. De resultaten laten zien dat deelnemers vooral de leerganggroep waarderen (inclusief de twee programmaleiders) en deze groep zien als een waar- devolle leergemeenschap. Dit werd in 44 van de formulieren genoemd. Figuur 2 geeft een compilatie van deze spontane opmerkingen over de community als meest gewaardeerde aspect van de leergang.}

De eindevaluaties van de drie edities van de leergang versterken het idee dat het functioneren als een community een essentieel ingrediënt was van de leergang. De leergang was bewust zo opgezet om dit te bewerkstelligen. Er was voldoende tijd voor informele ontmoetingen tussen de deelnemers en voor discussies in kleine groepen. Ook de beperkte groepsomvang (elf, dertien, veertien deelnemers per leergang) en de activerende aanpak van de besprekingen droegen daaraan bij. De meeste deelnemers gaven aan dat ze na de leergang graag bij elkaar wilden blijven komen.

Alle geïnterviewde docenten bevestigden het belang van de communityvorming in de leergang voor hun leren. Ze verklaarden allemaal dat hun collega-deelnemers in de leergang een zeer belangrijke bron van inspiratie zijn geweest. Wat de geïnterviewden vertelden komt grotendeels overeen met de uitkomsten op de evaluatieformulieren (zie figuur 2).

Een ander aspect dat spontaan naar voren kwam in de evaluatieformulieren was de waardering voor onderbouwde en recente theorie, de evidence-based benadering, plus de kritische reflectie die daarop mogelijk was. Zulke opmerkingen wer- 
Veel theorie en integratie daarvan; Hoog niveau van reflectie; Goede evidentie over community's; Heb veel geleerd over docentkwaliteit; Echt nieuwe inzichten; Inspirerende discussie met gastsprekers; Competentie van de sprekers; Goed niveau van verdieping in de presentaties en de discussie; Interesante theorie over kwaliteiten van honoursstudenten en docenten; Vooroordelen uitgedaagd; Conceptueel sterk overzicht van de theorie; Geweldige verdieping van mijn inzicht in honoursonderwijs en -didactiek.

\section{Figuur 3 De solide theoretische onderbouwing in de leergang honours teaching:} enkele uitspraken uit de evaluatieformulieren

den gemaakt in 24 van de evaluatieformulieren. Figuur 3 geeft een overzicht van enkele opmerkingen die in deze categorie vallen.

De eindevaluaties met het panel in de derde bijeenkomsten en de interviews bevestigen dat de deelnemers het kennisniveau en het open debat van de sprekers waardeerden evenals het feit dat ze informatie uit onderzoek naar honoursdidactiek en onderwijsexperimenten presenteerden. De deelnemers voelden zich aangesproken als ervaren docenten en academici en hadden het gevoel dat ze welkom waren om hun vragen, kritiek en ervaringen in de discussies in te brengen, zowel in de presentaties van de gastsprekers als in gesprek met de programmaleiders. In een van de interviews zei een deelnemer: "Het was belangrijk om theoretische onderbouwing te krijgen voor verschillende aspecten van honoursonderwijs en dit te bediscussiëren met gelijken". Zij voegde hieraan toe dat ze het leergangformat had gewaardeerd dat aanstuurde op "uit je routine komen, de diepte ingaan en aangesproken worden op een passend niveau". Een andere geïnterviewde docent benadrukte dat het voor hem belangrijk was geweest om "in contact gebracht te worden met goed en recent onderzoek over honoursonderwijs, experts te ontmoeten, en onderzoeksartikelen over honoursonderwijs en gerelateerde theorieën te bestuderen". Verschillende docenten gaven ons de feedback dat het voor hen essentieel was geweest om nieuwe inzichten aan de praktijk te koppelen, zoals van hen gevraagd werd in hun interventies (exerimentele aanpassingen in hun eigen honoursdidactiek, uitgevoerd gedurende de vier à vijf maanden tussen de eerste en de laatste bijeenkomst). Zo konden hun nieuw verworven inzichten wortel schieten en konden ze zich deze eigen maken.

Minder docenten noemden spontaan de geboden vrijheid als een sterk vormgevingsaspect van de leergang (in zestien van de evaluatieformulieren werd dit genoemd). Maar vrijheid werd wel duidelijk gezien als een kwaliteitsaspect van de leergang dat hun de mogelijkheid gaf om hun eigen vragen en zorgen in te brengen in de discussies, hun eigen interventie te kiezen en mee te bepalen welke thema's aan de orde moesten komen in de tweede bijeenkomst van de leergang. Figuur 4 geeft enkele opmerkingen die respondenten gaven met betrekking tot de vrijheid die hen werd geboden. 
Tijd hebben om met elkaar te praten; Ruimte om ideeën uit te wisselen; Voorkeuren van deelnemers meegenomen in de programmering; Runtime voor gesprekken; Veel ruimte voor discussie en het uitwisselen van ervaringen; Goed dat we individuele besprekingen hebben met de programmaleiders over onze zelfgekozen interventies; Tijd om na te denken; Goed dat we onze eigen honoursonderwerpen in kunnen brengen.

\section{Figuur 4 De gebonden vrijheid in de leergang honours teaching: enkele uitspraken uit de evaluatieformulieren}

Uit de interviews kwam duidelijk naar voren dat allerlei elementen die we hebben gebruikt om de community vorm te geven, hielpen om een gevoel van vrijheid te creëren: tijd in het programma om elkaar te spreken, de vrijheid om vragen of zorgen in de discussies in te brengen, om thema's of benaderingen voor de volgende bijeenkomst voor te stellen, om af te wijken van voorgestructureerde opdrachten voor groepswerk, om lectuur te kunnen kiezen (van de leestafel en van de cursusmaterialen) en om persoonlijke leerdoelen te stellen. Verder hadden alle deelnemers de mogelijkheid om een eigen interventie te kiezen (experiment in hun eigen honoursonderwijs) als onderdeel van de leergang.

De drie ontwerpelementen hangen samen en er kan er geen enkele worden weggelaten. Communityvorming zorgt voor een klimaat waarin van en met elkaar geleerd kan worden in de vrije ruimte in het programma. Een goed leerklimaat waarin de deelnemers zich positief en open opstellen en elkaars gedrevenheid en ervaring herkennen, vormt de basis voor open uitwisseling en voor reflectie over de toepasbaarheid van theoretische noties. De deelnemers zijn vrij om hun eigen project te kiezen waar ze gedurende de leergang aan willen werken, omdat dit hen uitdaagt en het voor henzelf en hun departement nuttig is. Voor dit project zoeken ze theoretische onderbouwing en de vertaling daarvan naar de praktijk met behulp van de inbreng van ervaringen van de andere deelnemers in de leergang. De behoefte aan theoretische onderbouwing maakte het zinvol om als groep bij elkaar te komen en van en met elkaar te leren. Zo blijken de community, de gebonden vrijheid en de ontwikkeling van academische competenties elkaar steeds te versterken.

\section{Conclusie en discussie}

Onze onderzoeksvraag was of de drie belangrijke strategieën van honoursdidactiek voor studenten zoals Wolfensberger (2012) die benoemt - het vergroten van academische competentie, bieden van vrijheid om eigen keuzes te maken en communityvorming - ook tot goede leerresultaten leiden in een leergang voor honoursdocenten.

De resultaten van dit onderzoek onderbouwen dit. De docenten die deelnamen aan de leergang honours teaching noemden deze drie componenten spontaan als pluspunten van de leergang in hun antwoorden op open vragen in evaluaties en in 
de interviews die we hebben gehouden. Van deze drie componenten springt communityvorming eruit; deze wordt het vaakst genoemd als element dat het meest in positieve zin is opgevallen. De deelnemers waarderen de communityvorming zeer en herkennen de vormgevingselementen in de leergang die communityvorming bewerkstelligen. De ruimte in het programma voor uitwisseling werd zeer gewaardeerd. Communityvorming werd gestimuleerd door de betrokkenheid, de gemotiveerdheid voor goed onderwijs en de ervaring met honoursdidactiek die ze bij elkaar herkenden. Dit bevestigt het idee van het Center of Excellence in University Teaching dat er veel kennis en ervaring is in de departementen, die de verdere ontwikkeling van honoursonderwijs in de universiteit kan bevorderen. Door deelnemers theoretische onderbouwing te geven en hen uit te dagen om nieuwe inzichten te implementeren in hun eigen onderwijspraktijk ontstond een waardevolle leerervaring. Hoewel vrijheid minder werd herkend als vormgevingselement, waardeerden de deelnemers dit aspect als een belangrijke factor in hun leerervaring.

In dit artikel hebben we de ontwerpcomponenten onderzocht van een professionele ontwikkelingscursus over honoursdidactiek voor docenten van de Universiteit Utrecht. Hoewel we onze conclusies baseren op één format, zijn de conclusies volgens ons breder toepasbaar voor instituten die verdere professionalisering van universitaire docenten willen vormgeven, aangezien de waarde ervan tevens is aangetoond in de reeds lang lopende CEUT-leergang Onderwijskundig Leiderschap van de Universiteit Utrecht (Grunefeld \& Wubbels, 2009). Een cursusontwerp gebaseerd op de drie bestudeerde ontwerpcomponenten kan breder worden toegepast. Een cursusontwerp voor universitaire docenten zou moeten bevatten: vrijheid om relevante onderwerpen voor hun praktijk te bespreken, aangesproken worden als academisch expert inclusief stevige discussies rond theorie en communityvorming. Nader onderzoek in meer cursussen en in cursussen voor niethonours universitaire docenten is echter nodig om sterker bewijs te leveren voor deze uitspraak.

Inmiddels zijn er in Nederland ook op de hogescholen van Groningen, Leeuwarden, Rotterdam en Utrecht cursussen voor honoursdocenten opgezet en is er aan de Saxion-hogeschool een cursus in ontwikkeling. Het is waardevol om ook voor deze cursussen te onderzoeken of honoursdidactiek er aan de basis van het cursusontwerp ligt, wat de meerwaarde daarvan is en wat het effect daarvan is op de leeropbrengst. Onze ervaring is dat honoursdocenten vergelijkbare kenmerken vertonen met honoursstudenten. Honoursdocenten zijn zeer gemotiveerd voor onderwijs en voor het begrijpen van de behoeften van hun studenten, ze willen zich extra inspannen voor hen, hebben een reflectieve houding, willen zichzelf academisch uitdagen, zijn flexibel en creatief in hun onderwijspraktijk. Volgens Reis \& Renzulli (2010) bevat een definitie van begaafde studenten de componenten intelligentie, creativiteit en motivatie. Scager (2013) verdeelt deze componenten in zes factoren van getalenteerde studenten: intelligentie, creatief denken, openstaan voor ervaringen, doorzettingsvermogen, de wil om te leren, en de behoefte om te excelleren. Deze gelijkenis in behoeften en karakteristieken kan 
een verklarende factor zijn voor de reden waarom dezelfde ontwerpcomponenten voor de leeromgeving bij beide groepen passen.

\section{Referenties}

Achterberg, C. (2005). What is a Honors Student? Journal of the National Collegiate Honors Council, Online Archive. Paper 170, 75-84. Geraadpleegd via http://digitalcommons.unl .edu/nchcjournal/170.

Clark, L. (2000). A review of the research on personality characteristics of academically talented college students. In C. Fuiks \& L. Clark (Eds.), Teaching and learning in honors (pp. 7-20). Radford, VA: The National Collegiate Honors Council.

Clausen, K.W., Aquino, A., \& Wideman, R. (2009). Bridging the real and ideal: A comparison between learning community characteristics and a school-based case study. Teaching and Teacher Education, 25, 444-452.

Deci, E.L., \& Ryan, R.M. (1985). Intrinsic Motivation and Self-Determination in Human Behavior. New York/London: Plenum Press.

Garet, M., Porter, A., Desimone, L., Birman, B., \& Yoon, K.S. (2001). What makes a professional development effective? American Education Research Journal, 38 (4), 915-945.

Gruber, H., \& Mandl, H. (2000). Instructional psychology and the gifted. In Heller, F.J. Mönks, F.J. Sternberg \& R.F. Subotnik (Eds), International handbook of giftedness and talent (pp. 383-396). Oxford: Elsevier Science.

Grunefeld, H., \& Wubbels, T. (2009). Onderwijskundig leiderschap (stimu)leren. Thema, 4, 43-49.

Guskey, T. (2005/2006). A conversation with Thomas A. Guskey. The Evaluation Exchange, XI, 4, Winter 2005/2006, 12-14. Geraadpleegd via http://www.hfrp.org/evaluation/ the-evaluation-exchange/issue-archive/professional-development/a-conversationwith-thomas-r.-guskey.

Kaczvinsky, D.P. (2007). What is an Honors Student? A Noel-Levitz Survey. Journal of the National Collegiate Honors Council, Fall/Winter, 8, 2, 87-95.

Kanevsly, L., \& Keighly, T. (2003). To produce or not to produce? Understanding the boredom and the honor in underachievement. Roeper Review, 26, 1, 20-28.

Marra, R., \& Palmer, B. (2004). Encouraging intellectual growth: Senior college students profiles. Journal of Adult Development, 11 (2), 281-288.

Reis, S.M., \& Renzulli, J.S. (2010). Is there still a need for gifted education? An examination of current research. Learning and Individual Difference, 20, 308-317.

Rinn, A.N., \& Plucker, J.A. (2004). We recruit them, but then what? The educational and psychological experiences of academically talented undergraduates. Gifted Child Quarterly, 48, 1, 54-67.

Rogers, K.B. (2007). Lessons learned about educating the gifted and talented: A synthesis of the research on educational practice. Gifted Child Quarterly, 51, 382-396.

Ryan, R.M., \& Deci, E.L. (2000). Self-determination Theory and the Facilitation of Intrinsic Motivation, Social Development, and Well-Being. American Psychologist, 55, 1, 68-78.

Scager, K. (2013). Hitting the high notes. Challenge in teaching honors students. Utrecht University, dissertation.

Shore, B.M., \& Kanevsky, L.S. (1993). Thinking processes: Being and becoming gifted. In Heller, F.J. Mönks \& A.H. Passow (Eds), International handbook of research and development of giftedness and talent (pp. 133-147). New York: Pergamon.

Snow, R.E., \& Swanson, J. (1992). Instructional psychology: Aptitude, adaptation, and assessment. Annual Review of Psychology, 43, 583-626. 
Van Eijl, P.J., Wolfensberger, M.V.C., \& Pilot, A. (2008). Talentontwikkeling bij Amerikaanse honours programma's en honours colleges. Site visitors van de National Collegiate Honors Council over talentontwikkeling. Utrecht: Interfacultair Instituut voor Lerarenopleiding, Onderwijsontwikkeling en Studievaardigheden.

Van Ginkel, S., Van Eijl, P., Pilot, A., \& Zubizarreta, J. (2012). Building a vibrant honors community among commuter students. Journal of the National Collegiate Honors Council, Honors Around the Globe, 13, 2, 197-218.

Van Tassel-Baska, J., \& Brown, E.F. (2007). Toward the best practice: An analysis of the efficacy of curriculum models in gifted education. Gifted Child Quarterly, 51, 4, 342-358.

Wolfensberger, M.V.C. (2012) Teaching for Excellence. Honors Pedagogies revealed. Münster: Waxmann. 